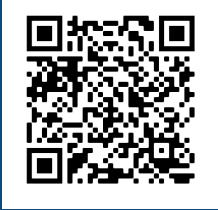

Keywords:

RUSLE

Soil conservation

Water erosion

Riparian forest

Historic:

Received 18/1 1/2019

Accepted 15/04/2020

Correspondence: simoes.ingridh@gmail.com
Guilherme Henrique Expedito Lense ${ }^{\text {la }}$, Rodrigo Santos Moreiralb, Taya Cristo Parreiras ${ }^{l c}$, Luis Felipe Pigatto Miranda Silva ${ }^{l d}$, Alexandre Elias de Miranda Teodorole, Ronaldo Luiz Mincatoff+

\section{SIMULATING THE EFFECT OF PERMANENT PRESERVATION AREAS ON SOIL EROSION RATES}

LENSE, G. H. E.; MOREIRA, R. S.; PARREIRAS, T. C.; SILVA, L. F. P, M.; TEODORO, A. E. M.; MINCATO, R. L. Simulating the effect of permanent preservation areas on soil erosion rates. CERNE, v. 26, n. 2, p.193-20I, 2020.

\section{HIGHLIGHTS}

The watershed does not have riparian forests around most of the watercourses.

The watershed has areas with soil losses above tolerable limits.

Areas with higher vegetation cover had lower soil losses.

Permanent preservation areas could reduce the soil loss in the watershed soil by $10 \%$.

\section{ABSTRACT}

Water erosion is one of the main problems faced by the Furnas Lake Surrounding Watershed, located in southeast Brazil. The erosive process is intensified by inadequate land occupation of the lake margins where should be riparian forests, or permanent preservation areas (APP), in order to protect water resources. In this context, our work aimed to estimate the soil losses of this watershed using the Revised Universal Soil Loss Equation (RUSLE) in two different scenarios: I - considering the actual occupation of the area, and II - building an alternative scenario where permanent preservation areas were present. Therefore, we considered physical, edaphoclimatic, and land use and management factors. To simulate the presence of preservation areas, we based it on the Brazilian Forest Code (Bill no. I2.65I/20I2). In the real scenario (I), the total soil loss estimated was $31,580,907.47 \mathrm{Mg} . y e a r^{-1}$ (32\% over the Soil Loss Tolerance) with

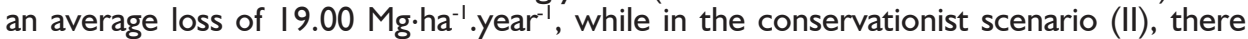
was $10 \%$ decrease, which means the mitigation of the erosion process as well as of the negative environmental impacts that can be generated by soil degradation. 


\section{INTRODUCTION}

Water erosion is one of the most important forms of soil degradation in Brazilian agriculture, and this problem can be aggravated by inadequate landuse and occupation, and by the lack of environmental management practices to soil conservation (Dechen et al., 2015; Cunha et al., 2017). High erosion rates can reduce agricultural productivity, cause siltation of watercourses, and decreasing water quality due to the transportation of sediments, nutrients and agrochemicals (Beskow et al., 2009).

Empirical models of prediction are useful tools to evaluate erosion rates and establish plans to reduce soil losses (Cunha et al., 2017). These models require easily obtainable and low-cost information, moreover, large scale water erosion evaluate is only possible with modeling techniques (Alewell et al., 2019). The Revised Universal Soil Loss Equation (RUSLE), developed by Renard et al. (1997), is a widely used model to estimate annual soil loss in watersheds (Ganasri and Ramesh, 2016) that requires low data input and overcome climatic and geographic restrictions (Bhandari et al., 2015). Associating the RUSLE with Geographic Information Systems (SIG), it is possible to produce maps to identify areas with an elevated risk of erosion and estimate the impacts of the different scenarios of land occupation, as well as the conservation practices effects on agricultural lands (Galdino et al., 2016).

Water erosion is one of the main issues faced by the Furnas Lake Surrounding Watershed, located in southeast Brazil. This watershed has a high capacity to produce water and a national strategic role in electricity production. The erosive process is intensified by the inappropriate land occupation of the lake margins with crops and pasture, eliminating the riparian forests or permanent preservation areas (APP), removing the protection of water resources (IGAM, 20I3). According to the Brazilian Forest Code, the watercourses margins should be designated to Permanent Preservation Areas (APP) and, being covered or not with native vegetation, have the function of preserve water resources and biodiversity, protect the soil and ensure the well being of the communities (Brasil, 20I2).

The identification of critical areas is fundamental to implement erosion mitigation practices and achieve an effective soil conservation program (Ganasri and Ramesh, 2016). Moreover, public policies concerning agriculture and the environment can generate effects on the erosion rates, reducing or amplifying them (Devátý et al., 2019). Therefore, our work aimed to estimate soil losses by water erosion over the Furnas Lake Surrounding Watershed using the Revised Universal Soil Loss Equation (RUSLE) in two different scenarios: I considering the actual land occupation, and II - building an alternative scenario where permanent preservation areas were present around the lake.

\section{MATERIAL AND METHODS}

\section{Study site}

The state of Minas Gerais is separated into 36 Water Resources Planning and Management Units (WRPMU), which are characterized by physical, socio-cultural, economic, and political aspects (IGAM, 20I3). The Furnas Lake Surrounding Watershed belongs to the Rio Grande hydrographic Basin and is one of the WRPMU called GD3. Furnas Hydroelectric Plant is located in the GD3 (Figure I), which presents an area of $16,643.00 \mathrm{~km}^{2}$ and covers 48 municipalities with an estimated population of $842,260.00$ inhabitants (IBGE, 20I I). The predominant climates on the area are, according to Köppen classification, subtropical highland ( $\mathrm{Cwb}$ ) and humid subtropical (Cwa) (Alvares et al., 2013). The average annual temperature range between $2 \mathrm{I}$ and $23^{\circ} \mathrm{C}$, and the average annual precipitation, between I 300 and I600 millimeters (IGAM, 20 I3).

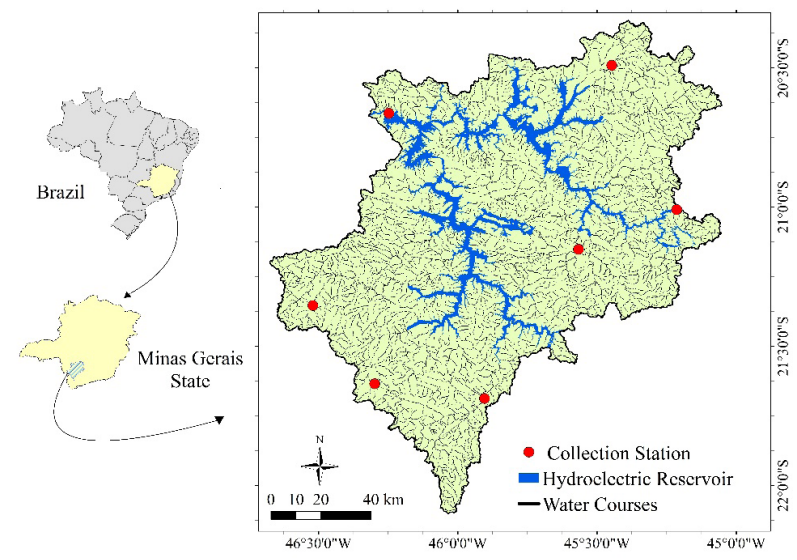

FIGURE I Location of the Furnas Lake Surrounding Watershed and the sediment collection stations of the Instituto Mineiro de Gestão das Águas, Minas Gerais, Brazil.

\section{Revised Universal Soil Loss Equation (RUSLE)}

The Revised Universal Soil Loss Equation (RUSLE) estimates the average soil loss of a given area according to Equation I (Renard et al., 1997). The parameters, data processing, and the modeling itself were developed on ArcMap 10.3 (ESRI, 20I5), using the Spatial Analyst extension, where, $A=$ average annual soil loss $\left(\mathrm{Mg} \mathrm{ha}^{-1}\right.$ year $\left.{ }^{-1}\right) ; R=$ rainfall erosivity factor $\left(M J m h^{-1} h^{-1}\right.$ year'); $\mathrm{K}=$ soil erodibility factor $\left(M g \cdot \mathrm{ha}^{-1} \mathrm{MJ}^{-1} \mathrm{~mm}^{-1}\right)$; $\mathrm{LS}=$ 
topographic factor, given by the relation between the relief length (L) and declivity (S) (dimensionless); $\mathrm{C}=$ cover and management factor (dimensionless); $\mathrm{P}=$ conservation practices factor (dimensionless).

$\mathrm{A}=\mathrm{R} \cdot \mathrm{K} \cdot \mathrm{LS} \cdot \mathrm{C} \cdot \mathrm{P}$

Rainfall erosivity $(\mathrm{R})$

The R-factor represents the potential of a pluviometric precipitation to disaggregate particles of an unprotected soil. This factor takes into consideration the total precipitation and the kinetic energy of rainfall drops on the soil (Beskow et al., 2019). Due to the lack of detailed registers about the basin rainfalls, we generated a geographic and multivariate model to the southeast region of Brazil, as proposed by Mello et al. (2013) (Equation 2), which allows to estimate the average annual rainfall erosivity using the latitude, longitude, and altitude from the study watershed. The calculation was executed on the Raster Calculator tool (ESRI, 2015) through each cell of the Digital Elevation Model (DEM), where, $R=$ rainfall erosivity factor ( $M J \mathrm{~mm} \mathrm{ha}^{-1} \mathrm{~h}^{-1}$ year-1); $A=$ average annual soil loss (Mg ha-I year-I); LA = latitude and LO = longitude, both in decimal negative degree.

$\mathrm{R}=-399433+420.49 \cdot \mathrm{A}-78296 \cdot \mathrm{LA}-0.01784 \cdot \mathrm{A}^{2}-1594.04 \cdot \mathrm{LA}^{2}+195.84 \cdot \mathrm{LO}^{2}+$

$17.77 \cdot \mathrm{LA} \cdot \mathrm{LO}-1716.27 \cdot \mathrm{LA} \cdot \mathrm{LO}+0.1851 \cdot \mathrm{LO}^{2} \cdot \mathrm{A}+0.00001002 \cdot \mathrm{LO}^{2} \cdot \mathrm{A}^{2}+1.389 \cdot$

$\mathrm{LA}^{2} \cdot \mathrm{LO}^{2}+0.01364 \cdot \mathrm{LA}^{2} \cdot \mathrm{LO}^{3}$

The R-factor values for the watershed ranged from 6. I 40 to $12.320 \mathrm{MJ} \mathrm{mm} \mathrm{ha}^{-1} \mathrm{~h}^{-1}$ year-1 (Figure 2).

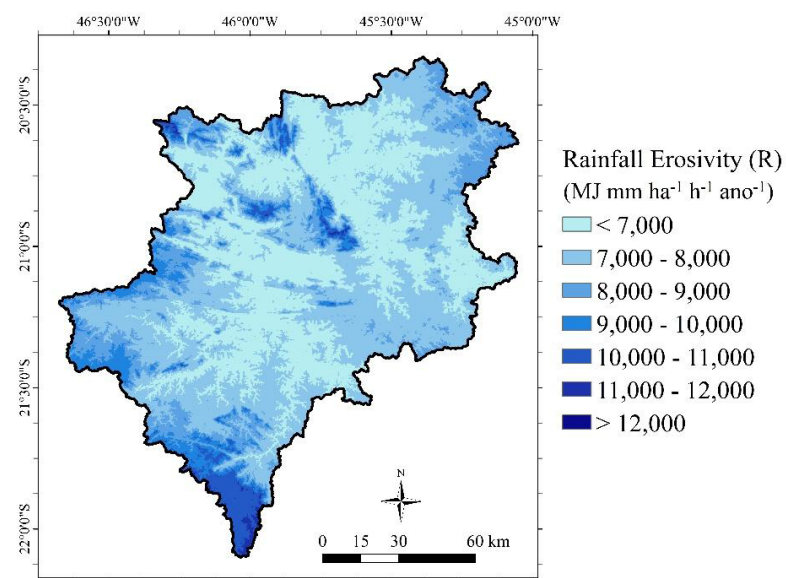

FIGURE 2 Rainfall erosivity factor (R) for the Furnas Lake Surrounding Watershed, Minas Gerais, Brazil.

Soil erodibility $(\mathrm{K})$

The K-factor represents the intrinsic soil susceptibility to water erosion according to its physical and chemical attributes. The values of this factor can be calculated by experimental plots, but field tests can be expensive and consume time (Beskow et al., 2009). Therefore, we resort to the specialized literature to determinate how resistant the basin soils are, using reported values (Sá et al., 2004; Silva and Alvares, 2005; Silva et al., 2009; Martins et al., 20II). The Map of the soils of Minas Gerais state (UFV et al., 2010) was employed as reference to define the spatial distribution of the K-factor (Figure 3).

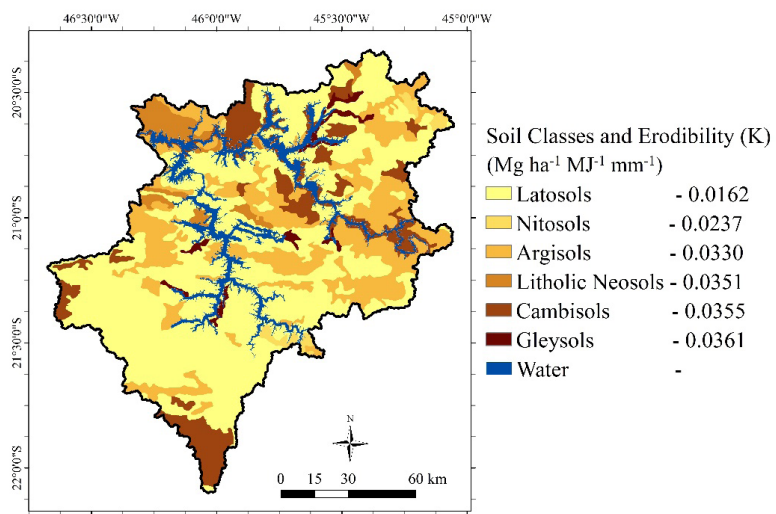

FIGURE 3 Digital map of the Soils and K-factor values for the Furnas Lake Surrounding Watershed, Minas Gerais, Brazil. K-factor was adapted from Sá et al. (2004), Silva and Alvares (2005), and Martins et al. (20I I).

The watershed soils were main classified as Latosols $(56.69 \%)$, followed by Argisols (22.45\%), Cambisols ( $10.53 \%)$, Litholic Neosols (3.54\%), Nitosols (I.34\%) and Gleysols (I.50\%).

Topographic factor (LS)

The LS factor expresses the topographic influence on soil erosion (Renard et al., 1997). We calculate this factor using Equation 3, proposed by Moore and Burch (1986), and the average obtained was 3.29 (Figure 4C), where, LS $=$ topographic factor (dimensionless); $F A=$ accumulation flow in the watershed, calculated from the DEM using the ArcMap I0.3 Flow accumulation tool (ESRI, 20I5); $\mathrm{S}=$ the basin declivity (degrees), where 30 is the spatial resolution of the DEM cells, in meters. FA represents the redirection of runoff flows in the watershed.

$\mathrm{LS}=\left(\frac{\mathrm{FA} \cdot 30}{22.13}\right)^{0.4} \cdot\left(\frac{\sin (\mathrm{S})}{0.0896}\right)^{1.3}$

The Digital Elevation Model (Figure 4A) was elaborated using the level curves obtained in the Spatial Data Infrastructure of the Sistema Estadual de Meio Ambiente e Recursos Hídricos (SISEMA, 2019). Then, we produce the declivity map (Figure 4) through the Slope tool (ESRI, 2015). The altitude in the watershed range from $7 \mid 7$ to $I 470$ meters and the predominant relief is moderately undulating with an average inclination of $7.70 \%$. 


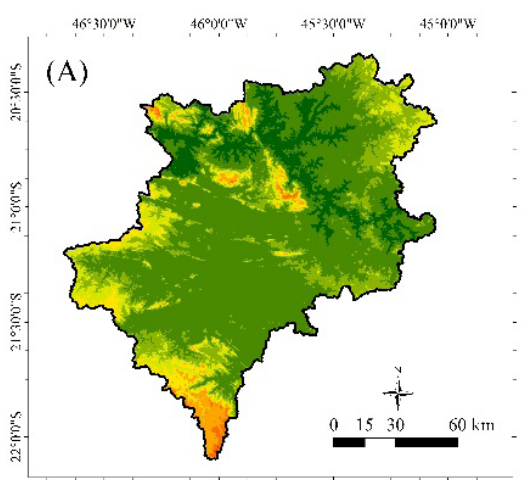

Digital Elevation Model (m)

$$
\begin{array}{ll}
\square<800 & \square 1,100-1,200 \\
=800-900 & 1,200-1,300 \\
-900-1,000 & 1,300-1,400 \\
\square & 1,000-1,100 \square>1,400
\end{array}
$$

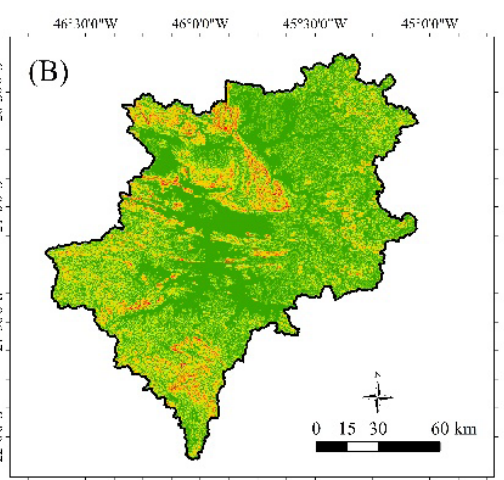

$$
\begin{aligned}
& \text { Slope (\%) } \\
& \square 0-5 \square 15-30 \\
& \square-5-10 \square 30-45 \\
& \square 10-15 \square>45
\end{aligned}
$$

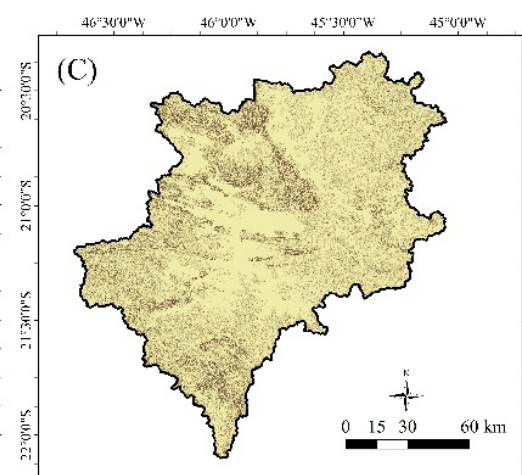

Topographic factor (LS)

$\square 0-2 \square 10-15$

$\square 2-5 \square 15-30$

$\square 5-10 \square>30$

FIGURE 4 Digital Elevation Model (A); Declivity map (B) and LS- Factor (C) for the Furnas Lake Surrounding Watershed, Minas Gerais, Brazil.

\section{Cover management factor (C)}

The $\mathrm{C}$-factor refers to the effect of the soil cover against erosion, it ranges from 0 to $\mathrm{I}$, according to the vegetation density, and higher values represent lower soil protection, due to the impact of the rainfall drops on the soil particles causing it degradation and an intensified surface runoff (Oliveira et al., 20।4).

Using the Map of land use of Minas Gerais state of 2018 (Projeto MapBiomas, 2018) as a reference, we elaborated the C-factor map. The watershed area is mainly occupied by pastures (38\%) and crops (37.1\%), followed by Atlantic Forest (10.19\%), Cerrado (4.4I\%), urbanization $(0.62 \%)$, bare soils $(0.08 \%)$ and water bodies (8.05\%) (Figure 5).

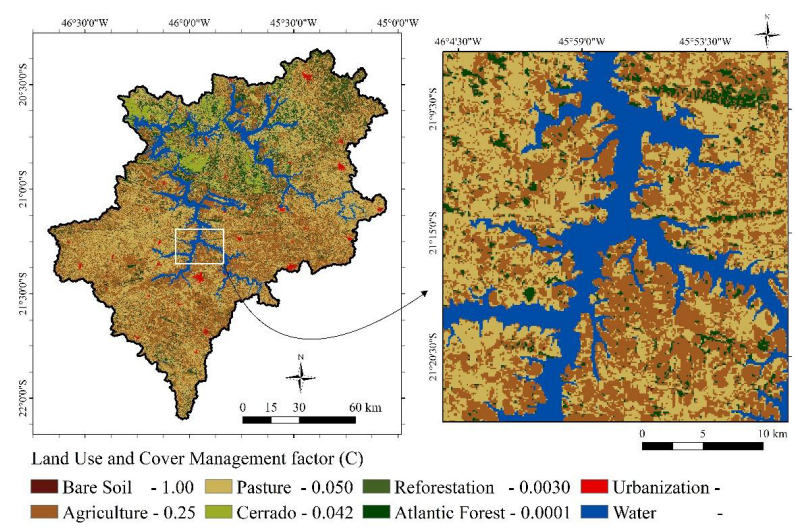

FIGURE 5 Land use map (adapted from the Projeto MapBiomas (20I8)) and C-factor (according to Farinasso et al. (2006), Silva et al. (2010) and Bertoni and Lombardi Neto (2012)).

The C-factor values, for each land-use class (Figure 5), were adapted according to Farinasso et al. (2006), Silva et al. (20I0), and Bertoni and Lombardi
Neto (20I2). Bare soils received the maximum value (I), while urban zones and water bodies were not considered on the soil loss equation.

\section{Conservation practices factor $(\mathrm{P})$}

The P-factor ranges from 0 to I which express the effect of management practices on soil loss reduction (Oliveira et al., 20l4). Due to the wide extent of the watershed, it was not possible to determine the conservation practices of the area. Thus, factor $P$ was calculated with slope as the key property for soil conservation practices (Silva et al., 2010; Medeiros et al., 2016). In slopes lower than $0.5 \%$, the value of $P=$ 0.6 was assumed, and in slopes higher than $20 \%$, we assumed $P=I$. For slopes between 0.5 to $20 \%$, the $P$ values of was defined according to Equation 4, Where, $P$ is the factor of conservationist practices (dimensionless), and $\mathrm{s}$ is the slope (\%).

$$
\mathrm{P}=0.69947-0.08911 \cdot \mathrm{s}+0.01184 \cdot \mathrm{s}^{2}-0.000335 \cdot \mathrm{s}^{3} \text {. }
$$

\section{Conservationist scenario simulation}

To evaluate the impact of the APP presence over water erosion on the Furnas Lake Surrounding Watershed, we built an alternative scenario as if the entire basin was partially adequate with sections I and II of the article 4th of the Brazilian Forest Code (Brasil, 20I2).

APPs with vegetation strips of $30 \mathrm{~m}$ were simulated for watercourses with less than 10 meters wide; $50 \mathrm{~m}$ for watercourses between 10 and $50 \mathrm{~m}$ wide; $100 \mathrm{~m}$ for watercourses above 50 meters. In the areas surrounding natural lakes and lagoons, the APPs were simulated with $100 \mathrm{~m}$ wide in rural areas and $30 \mathrm{~m}$ in urban areas. 
The APP delimitation around the Furnas Reservoir follows the provisions of the 62th article of the Brazilian Forest Code (Brazil, 20I2), that bounds the margins of artificial lakes, intended to generate electricity or public water supply, with concession or authorization previous the Provisory Measure (MP) no. 2.166-67, from august 24 th of $200 \mathrm{I}$, as a difference between the maximum normal operative level and the maximum operating quota for which the dam was designed.

The APP delimitation around the Furnas Reservoir followed the provisions of the 62 nd article of the Brazilian Forest Code (Brazil, 2012). The bill establishes that artificial lakes whose function is to generate electricity or to supply water, with concession or authorization previous the Provisory Measure (MP) 2.166-67, from August 24th, 200I, must have its margins transformed into preservation areas observing the difference between the maximum normal operating level and the maximum operating quota for which the dam was designed.

Considering that the maximum operative level of the lake is $768 \mathrm{~m}$ above sea level, and the maximum operating quota is $769.3 \mathrm{~m}$, the preservation areas would be short and distant from the ideal (Teixeira et al., 2017). Therefore, we built the scenario as if the implementation of the reservoir had occurred after the MP, and we designated $30 \mathrm{~m}$ of APP, as established by the code to artificial lakes located in urban zones, and $100 \mathrm{~m}$ of APP, for those located in rural areas (Brasil, 20I2).

The permanent preservation areas were simulated according to the width of the water courses, and to do so, we use the Buffer tool from ArcMap 10.3 (ESRI, 20I5). We obtained the hydrography data from the Sistema Estadual de Meio Ambiente e Recursos Hídricos (SISEMA, 2019), reclassifying latter the land-use map inserting this simulated vegetation margins (Figure 6).

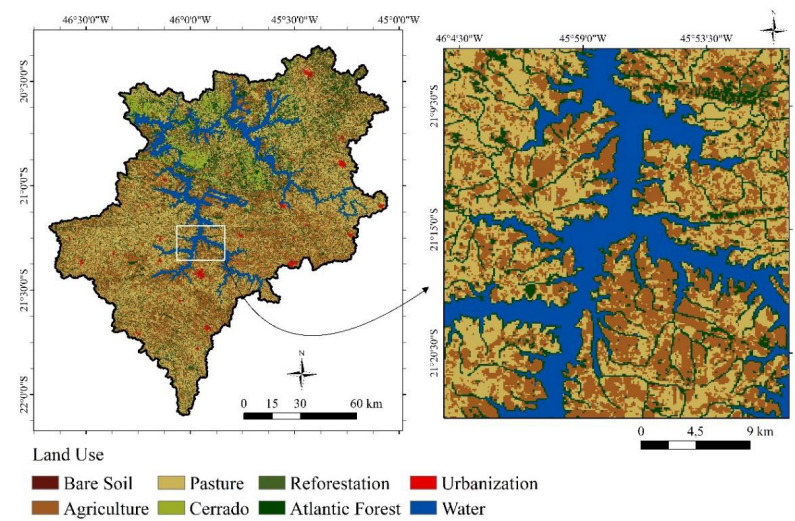

FIGURE 6 Simulation of the conservationist land use scenario in the Furnas Lake Surrounding Watershed, Minas Gerais, Brazil. Adapted from the Projeto MapBiomas (2018).

\section{RUSLE Validation}

The sediment production, or net erosion, is the eroded soil fraction transported to the water bodies, and it can be directly observed and measured in the field (which is usually done by the hydro sedimentologic stations), therefore, used to validate soil loss estimates. However, it is worth the mention that, the RUSLE estimates the total of soil erosion (gross erosion), which makes it necessary the integration of the model with the Sediment Delivery Rate (SDR) (Ebrahimzadeh et al., 20I8), that represents a relationship between the gross and the net erosion. The SDR was then determined by employing Equation 5 proposed by Varoni (1975), Where, SDR = sediment delivery rate (\%); $A=$ watershed area $\left(\mathrm{km}^{2}\right)$.

$S D R=0.472 \cdot A^{-0.125}$

The net erosion observed in the field was acquired using data of the total of transported sediment in the water discharge and of the daily flow, as proposed by Beskow et al. (2009). Initially, we built a curve relating the total of transported sediment and the water discharge of the watershed (Figure 6) with data from hydro-sedimentologic stations operated by the Instituto Mineiro de Gestão das Águas (IGAM), monitored from 2001 to 2018 (Figure 7).

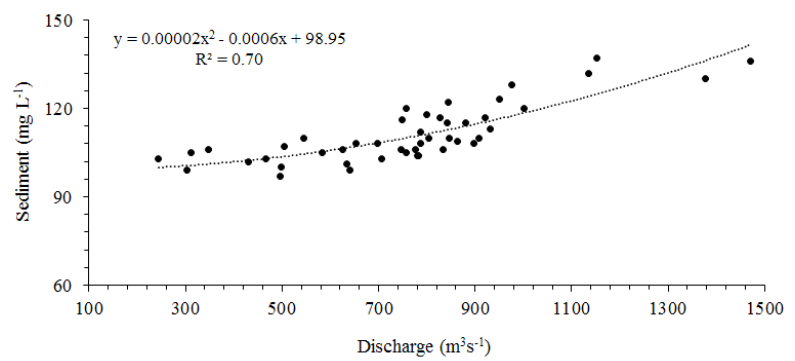

FIGURE 7 Water discharge curve (sediment transported $\times$ water discharge) in the Furnas Lake Surrounding Watershed, Minas Gerais, Brazil.

The annual transportation of sediments was calculated considering the flow versus sediment curve and the dataset of daily flow obtained from the Agência Nacional de Águas (ANA, 2019). The observed net erosion was then compared with the soil loss estimate provided by RUSLE.

\section{RESULTS AND DISCUSSION}

\section{Gross Erosion}

Gross water erosion in the watershed was estimated at 3I,580,907.47 Mg year-I. Areas with high slope are those with higher values for the LS-factor and, 
therefore, presented an intensified erosion process (Figure 8). According to Beskow et al. (2009) and Avanzi et al.

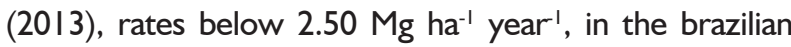
edaphoclimatic conditions, can be considered as lowintensity erosion, while losses above $15.00 \mathrm{Mg} \mathrm{ha}^{-1}$ year', represent high risks.

Despite the predominance of water erosion of weak intensity ( $60 \%$ of the basin), about $30 \%$ of the area demonstrated being suffering with severe soil loss, reaching values higher than $100 \mathrm{Mg} \mathrm{ha}^{-1}$ year-1. Higher rates locations bias the average soil loss of the watershed,

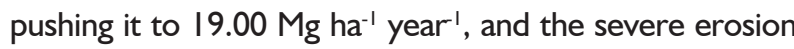
is distributed all over the area, reinforcing the need to plan conservationist measures and to manage the mitigation of the process.

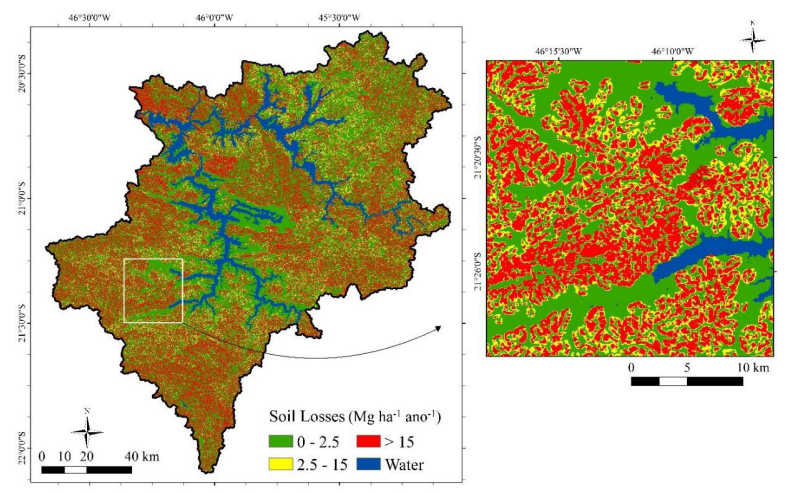

FIGURE 8 Soil Loss Rates in the Surrounding Basin of Furnas Lake, Minas Gerais, Brazil.

Considering the land use and occupation classes, the higher soil losses were detected in bare soil areas (40.70 $\mathrm{Mg} \mathrm{ha}^{-1}$ year $^{-1}$ ), followed by agriculture (36.17 $M g \mathrm{~h}^{\mathrm{a}-1}$ year $^{-1}$ ), cerrado (3l.18 $\mathrm{Mg} \mathrm{ha}^{-1}$ year-1), pastures ( $12.20 \mathrm{Mg} \mathrm{ha}^{-1}$ year $\left.^{-1}\right)$, reforesting $\left(0.62 \mathrm{Mg} \mathrm{ha}^{-1}\right.$ year $\left.^{-1}\right)$ and Atlantic Forest $\left(0.07 \mathrm{Mg} \mathrm{ha}^{-1}\right.$ year-1 $\left.^{-1}\right)$.

The variation of these rates is related to the C-factor, once high-density vegetation cover (lower C-factor) led to lower losses. A significative portion of the watershed has elevated R-factor (rainfall erosivity), steep relief, and high vulnerability to water erosion, so the soil cover, as well as management practices, can help to attenuate the degradation process. Beskow et al. (2009) also obtained similar results in a watershed located in the same region.

Bare soil areas are concentrated mostly around the hydroelectric reservoir once there was a decrease in its storage volume. Therefore, it is necessary to reforest these spaces, seeking to increase soil protection against the negative effects of the rainfalls, to reduce erosion and the lake siltation.
Agricultural lands also need the adoption of conservationist practices, such adoption of the no-till system, management of plant residues, terracing and level planting, and this task is a responsibility of the farmers, once erosion causes loss of nutrients, organic matter, and agrochemicals, which can harm the agricultural production (Avanzi et al. 20l3).

The watershed estimated soil losses were compared to the limits of the Soil Loss Tolerance $(T)$. We adopt the following limits: $5.21 \mathrm{Mg} \mathrm{ha}^{-1}$ year-1 for Litholic

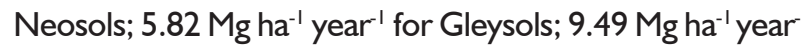
I for Cambisols; $9.78 \mathrm{Mg} \mathrm{ha}^{-1}$ year-1 for Nitosols; $10.50 \mathrm{Mg}$ ha $^{-1}$ year $^{-1}$ for Argisols; and 12.50 $\mathrm{Mg} \mathrm{ha}^{-1}$ year $^{-1}$ for Latosols (Mannigel et al., 2002; Oliveira et al., 2008).

About $32 \%$ of the basin presented losses above the $T$ limits, which turn them into priority areas to adopt mitigation actions. The areas with soil losses above T (5,325.80 km2) are located mainly under Latosols (49\%), followed by Argisols (29\%), Cambisols (13\%), and Litolic Neosols (6\%). Moreover, these areas are mostly occupied by agricultural (48\%) and pasture (4I\%). This result strengthens the need for the adequacy of land use and occupation planning in the hydrographic basin according to agricultural suitability of soils, mainly the Neosols and Cambisols, which present high susceptibility to erosion and low $\mathrm{T}$ limits. Moreover, is essential to recover the degraded pastures and adopt conservation practices in the subbasin area to avoid soil losses. It is worth the mention that Soil Loss Tolerance sets the limits where the soil losses are manageable in the short term. However, practices to reduce erosion and ensure long-term soil sustainability must still be pursued.

\section{Net Erosion}

The sediment delivery rate (SDR) calculated was $14.0 \%$ indicating a net erosion of $4,421,327.05 \mathrm{Mg}$ year-I, which shows how much sediments achieve the watershed water bodies. Along with the lake siltation, these residues transport nutrients, especially nitrogen $(\mathrm{N})$ and phosphorus $(\mathrm{P})$, leading into eutrophication and deterioration of the water quality (Chen et al., 2016). The net erosion observed in the field, used as validation, was $2.17 \mathrm{Mg} \mathrm{ha-1}$ year-I, which means that RUSLE overestimated the losses by $0.81 \mathrm{Mg} \mathrm{ha}^{-1}$ year ${ }^{-1}$, with an absolute error of $37 \%$. However, considering the large work scale $\left(16,222.06 \mathrm{~km}^{2}\right)$, it is tolerable.

Erosion modeling is a representation of reality, not the reality itself, therefore, subject to errors (Alewell et al., 2019).Thus, despite the difference between model and validation, the application of RUSLE provided satisfactory results and accomplished its objective of 
being an accessible predictive tool, capable of providing a reliable diagnosis of the water erosion process.

\section{Conservationist scenario}

By simulating a conservationist scenario, we noticed a $50 \%\left(57.85 \mathrm{~km}^{2}\right)$ increase of forests in the watershed area. The simulated permanent preserved areas afforded a $10 \%$ decrease of the net erosion, representing $438,300.00 \mathrm{Mg}$ year-I of soil that is no longer deposited in watercourses. That reduction can be higher than the observed, once these areas act like a physical barrier that retains the eroded soil into the basin, which is not taking into consideration by the RUSLE.

Over $60 \%$ of the basin presented gross erosion of weak intensity in the actual scenario, while in the conservationist scenario, $65 \%$. Introducing the APP, the proportion of high-intensity erosion was reduced to $27 \%$, and sites with soil losses above the $\mathrm{T}$ limits decreased from $32.0 \%$ to $29.0 \%$, which is equivalent to a reduction of $486.65 \mathrm{~km}^{2}$.

APPs also can improve water quality by decreasing the direct transfer of nutrients and contaminants to watercourses (Bispo et al., 2017). Also, vegetation in the margins could increase the reservoir lifetime by reducing siltation.

It is worth the mention that the present study simulated the implementation of permanent preservation areas and their effects, without considering the social and economic aspects involved in the implementation of such areas. However, the possibility of implementing long-term measures that favor the growth of marginal vegetation should be considered in the river basin management planning, once the reduction of water erosion is one of the many ecosystem benefits and services that APP can provide to the environment. In addition to the recovery of APPs, the Government should increase the inspection of illegal deforestation, to ensure that the current APP conservation scenario is closer to that provided in the Brazilian Forest Code (Brasil, 20I2).

\section{CONCLUSIONS}

The Revised Universal Soil Loss Equation (RUSLE) satisfactorily simulated the erosion process and pointed to higher soil loss rates in areas of steep relief, especially when occupied with crops or bare soil. The model allowed to determine areas with losses above the $\mathrm{T}$ limits (32.0\%), and those are a priority to the adoption of actions to control water erosion. The simulation of the permanent preservation areas led into a 10\% decrease of the soil losses, and given that, the implementation of permanent preservation areas could be an alternative to reduce water erosion and the reservoir siltation on the Furnas Lake Surrounding Watershed.

\section{ACKNOWLEDGMENTS}

To the Fundação de Amparo à Pesquisa do Estado de Minas Gerais (FAPEMIG), for the scholarship offered to the first author. To the Coordenação de Aperfeiçoamento de Pessoal de Nível Superior (CAPES), for the financing of the study - Financial Code 00I.

\section{REFERENCES}

ALEWELL, C.; BORRELLI, P.; MEUSBURGER, K.; PANAGOS, P. Using the USLE: Chances, challenges and limitations of soil erosion modelling. International Soil and Water Conservation Research, v. 7, n. 3, p. 203-225, 2019.

ALVARES, C. A.; STAPE, J. L.; SENTELHAS, P. C.; GONÇALVES, J. L. M.; SPAROVEK, G. Köppen's climate classification map for Brazil. Meteorologische Zeitschrift, v. 22, n. 6, p. 7II-728, 2013.

ANA, Agência Nacional de Águas. Sistema Nacional de Informações sobre Recursos Hídricos, 2019. Available at: https://www.snirh.gov.br/hidroweb/publico/ apresentacao.jsf. Accessed in: 10 october 2019.

AVANZI, J. C.; SILVA, M. L. N.; CURI, N.; NORTON, L. D.; BESKOW, S.; MARTINS, S. G. Spatial distribution of water erosion risk in a watershed with eucalyptus and Atlantic Forest. Ciência e Agrotecnologia, v. 37, n. 5, p. 427-434, 2013.

BERTONI, J.; LOMBARDI NETO, F. Conservação do solo. São Paulo: Ícone, 20I2. 360p.

BESKOW, S.; MELLO, C. R.; NORTON, L. D.; CURI, N.; VIOLA, M. R.; AVANZI, J. C. Soil erosion prediction in the Grande River Basin, Brazil using distributed modeling. Catena, v. 79, n. I, p. 49-59, 2009.

BISPO, D. F. A.; SILVA, M. L. N.; MARQUES, J. J. G. S. M.; BECHMANN, M.; BATISTA, P. V. G.; CURI, N. Phosphorus transfer at a small catchment in southeastern Brazil: distributed modelling in different land use scenarios. Ciência e Agrotecnologia, v. 4I, n. 5, p. 565-579, 2017.

BHANDARI, K. P.; ARYAL, J.; DARNSAWASDI, R. A geospatial approach to assessing soil erosion in a watershed by integrating socio-economic determinants and the RUSLE model. Natural Hazards, v. 75, n. I, p. 32I-342, 2015.

BRASIL. Lei Federal. Código Florestal Brasileiro - Lei n ${ }^{\circ}$ I2.65 I, DF: Congresso Federal, 2012. Available at: http:// www. planalto.gov.br/ccivil_03/_Ato20 I I2014/2012/Lei/ LI265I. htm. Accessed in: 24 october 2019.

CHEN, C.; GAO, M.; XIE, D.; NI, J. Spatial and temporal variations in non-point source losses of nitrogen and phosphorus in a small agricultural catchment in the Three Gorges Region. Environmental Monitoring and Assessment, v. 188, n. 257, p. I-15, 2016. 
CUNHA, E. R.; BACANI, V. M.; PANACHUKI, E. Modeling soil erosion using RUSLE and GIS in a watershed occupied by rural settlement in the Brazilian Cerrado. Natural Hazards, v. 85, n. 2, p. 85I-868, 2017.

DECHEN, S. C. F.; TELLES, T. S.; GUIMARÃES, M. F.; MARIA, I. C. Perdas e custos associados à erosão hídrica em função de taxas de cobertura do solo. Bragantia, v. 74, n. 2, p. 224-233, 2015.

DEVÁTÝ, J.; DOSTÁL, T.; HÖSL, R.; KRÁSA, J.; STRAUSS, P. Effects of historical land use and land pattern changes on soil erosion - Case studies from Lower Austria and Central Bohemia. Land Use Policy, v. 82, n. I, p. 674-685, 2019.

EBRAHIMZADEH, S.; MOTAGH, M.; MAHBOUB, V.; HARIJANI, F. M. An improved RUSLE/SDR model for the evaluation of soil erosion. Environmental Earth Sciences, v. 77, n. 454, p. I-17, 2018.

ESRI, Environmental Systems Research Institute - Inc. ARCGIS Professional GIS for the desktop version 10.3. Redlands, Califórnia, EUA, Software, 2015. Available at: http://desktop.arcgis.com/en/arcmap/I0.3/get-started/ quick-start-guides/arcgis-desktop quick-start-guide.htm. Accessed in: 10 january 2019.

FARINASSO, M.; CARVALHO JÚNIOR, O. A.; GUIMARÃES R. F.; GOMES, R. A. T.; RAMOS, V. M. Avaliação qualitativa do potencial de erosão laminar em grandes áreas por meio da EUPS - equação universal de perdas de solos utilizando novas metodologias em SIG para os cálculos dos seus fatores na região do Alto Parnaíba PI-MA. Revista Brasileira de Geomorfologia, v. 7, n. 2, p. 73-85, 2006.

GALDINO, S.; SANO, E. E.; ANDRADE, R. G.; GREGO, C. R.; NOGUEIRA, S. F.; BRAGANTINI, C.; FLOSI, A. H. G. Large-scale Modeling of Soil Erosion with RUSLE for Conservationist Planning of Degraded Cultivated Brazilian Pastures. Land Degradation e Development, v. 27, p. 773-784, 2016.

GANASRI, B. P.; RAMESH, H. Assessment of soil erosion by RUSLE model using remote sensing and GIS - A case study of Nethravathi Basin. Geoscience Frontiers, v. 7, n. 6, p. 953-96I, 2016.

IGAM, Instituto Mineiro de Gestão das Águas. Plano Diretor de Recursos Hídricos da Bacia Hidrográfica do Entorno do Lago de Furnas. Instituto Mineiro de Gestão das Águas; Alago - Fupai. Belo Horizonte: IGAM, 20I3. 305p.

IBGE, Instituto Brasileiro de Geografia e Estatística. Censo Demográfico 2010. Ministério do Planejamento, Orçamento e Gestão. Rio de Janeiro: IBGE, 20I I. 270p.

MANNIGEL, A. R.; CARVALHO, M. P.; MORETI, D.; MEDEIROS, L. R. Fator erodibilidade e tolerância de perda dos solos do Estado de São Paulo. Acta Scientiarum, v. 24, n. 5, p. I335-1340, 2002.
MARTINS, S. G.; AVANZI, J. C.; SILVA, M. L. N.; CURI, N.; FONSECA, S. Erodibilidade do solo nos tabuleiros costeiros. Pesquisa Agropecuária Tropical, v. 4I, n. 3, p. 322-327, 201 I.

MEDEIROS, G. O. R.; GIAROLLA, A.; SAMPAIO, G.; MARINHO, M. A. Estimates of Annual Soil Loss Rates in the State of São Paulo, Brazil. Revista Brasileira de Ciência do Solo, v. 40, e0I50497, 2016.

MELLO, C. R.; VIOLA, M. R.; BESKOW, S.; NORTON, L. D. Multivariate models for annual rainfall erosivity in Brazil. Geoderma, v. 203, p. 88-102, 2013.

MOORE, I. D.; BURCH, G. J. Physical basis of the length slope factor in the Universal Soil Loss Equation. Soil Science Society of America, v. 50, n. 5, p. 1294-1298, 1986.

OLIVEIRA, F. P.; SANTOS, D.; SILVA, I. F; SILVA, M. L. N. Tolerância de Perda de Solo por Erosão para o Estado da Paraíba. Revista de Biologia e Ciências da Terra, v. 8, n. 2, p. 60-7I, 2008.

OLIVEIRA, V. A.; MELLO, C. R.; DURÃES, M. F.; SILVA, A. M. Soil erosion vulnerability in the verde river basin, southern Minas Gerais. Ciência e Agrotecnologia, v. 38, n. 3, p. 262-269, 2014

PROJETO MAPBIOMAS. Coleção 4 da Série Anual de Mapas de Cobertura e Uso de Solo do Brasil, 2018. Available at: http://plataforma.mapbiomas.org/ map\#coverage. Accessed in: 24 october 2019

RENARD, K. G.; FOSTER, G. R.; WEESIER, G. A.; MCCOOL, D. K.; YODER, D. C. Predicting soil erosion by water: a guide to conservation planning with the Revised Universal Soil Loss Equation (RUSLE). Washington: United States Department of Agriculture, 1997. 384p.

SÁ, M. A. C.; LIMA, J. M.; CURI, N.; MASSAROTO, J. A.; MARQUES, J. J. G. S. M. Estimativa da erodibilidade pela desagregação por ultra-som e atributos de solos com horizonte $B$ textural. Pesquisa Agropecuária Brasileira, v. 39, n. 7, p. 691-699, 2004.

SILVA, A. M.; ALVARES, C. A. Levantamento de informações e estruturação de um banco de dados sobre a erodibilidade de classes de solos no Estado de São Paulo. Geociências, v. 24, n. I, p. 33-42, 2005.

SILVA, A. M.; SILVA, M. L. N.; CURI, N.; AVANZI, J. C.; FERREIRA, M. M. Erosividade da chuva e erodibilidade de Cambissolo e Latossolo na região de Lavras, sul de Minas Gerais. Revista Brasileira de Ciência do Solo, v. 33, n. 6, p. I8II-1820, 2009.

SILVA, F. G. B.; MINOTTI, R. T.; LOMBARDI NETO, F; PRIMAVESI, O.; CRESTANA, S. Previsão da perda de solo na Fazenda Canchim - SP (EMBRAPA) utilizando geoprocessamento e o USLE 2D. Engenharia Sanitária e Ambiental, v. I5, n. 2, p. |4I-|48, 2010. 
SISEMA. Infraestrutura de Dados Espaciais do Sistema Estadual de Meio Ambiente e Recursos Hídricos. Belo Horizonte: IDE-Sisema, 2019. Available at: idesisema. meioambiente.mg.gov.br. Accessed in: 10 october 2019.

TEIXEIRA, L. P. T.; NISHIMOTO, M.; TRINDADE, C.A.; NUNES, J.C.S. Delimitação da área de preservação permanente na represa da usina hidrelétrica de furnas com $\circ$ uso de técnicas fotogramétricas. Blucher Engineering Proceedings, v. 4, n. 2, p. I-I0, 2017.
UFV - CETEC - UFLA - FEAM, 20I0. Mapa de solos do Estado de Minas Gerais. Belo Horizonte, Fundação Estadual do Meio Ambiente, 2010. 49p. Available at: http:// www.feam.br/noticias/I/949-mapas-de-solo-doestado-de-minas-gerais. Accessed in: 10 october 2019.

VANONI, V. A. Sediment deposition engineering. American Society of Civil Engineers, Manuals and Reports on Engineering Practice, 1975. 745 p. 